\title{
Implementation of Adolescent Reproductive Health Policies in Bandung District
}

\author{
$1^{\text {st }}$ Nurhayati \\ Sekolah Tinggi Ilmu Kesehatan \\ 'Aisyiyah Bandung \\ nurha1410@gmail.com
}

\author{
$2^{\text {nd }} \mathrm{F}$ Handayani \\ Sekolah Tinggi Ilmu Kesehatan \\ 'Aisyiyah Bandung \\ Bandung, Indonesia
}

\author{
$3^{\text {rd }}$ A Kamila \\ Sekolah Tinggi Ilmu Kesehatan \\ 'Aisyiyah Bandung
}

\begin{abstract}
One of the efforts to equip adolescents is to make policies on adolescent reproductive health that can accommodate the needs of adolescents in educational institutions or schools. This study aims to determine the implementation of learning policies on adolescent reproductive health programs or the likes. Method: This research is a descriptive exploratory study to describe phenomena systematically. Informant research are students as recipients, implementers and policymakers. Sampling uses a purposive sampling technique. Data collection is done by observation, interview and documentation techniques. Data analysis includes interview results in the form of transcripts, coding and data reduction, presentation of data in the form of themes and interpreting and drawing conclusions from the results of the analysis. Results: The results showed there was a discrepancy in some indicators of the success of the implementation of the policy namely an indicator of communication, human resources and bureaucratic structure, while the disposition indicator showed the commitment of the policy implementers to implement the program. Conclusion: The implementation of reproductive health education policy is felt not to be good and optimal in terms of communication, resources, disposition and bureaucratic structure. Commitment to improvement is needed in order to quality improvement.
\end{abstract}

Keywords-implementation, adolescents reproductive health, policies

\section{INTRODUCTION}

Stages of human development have characteristics at each stage. Each stage of development requires attention and should be recognized so that nothing deviating occurs, including in the adolescent age group. Based on the results of the Directorate General of PP\&PL Ministry of Health of the Republic of Indonesia (2014) quoted from Nuraldila et al (2017) there were 3,661 people aged 15-24 years in Indonesia who were infected with HIV in 2012, 5,551 in 2013 and 4,400 residents in 2014 and according to Demographic Survey Indonesia's Health on Adolescent Reproductive Health (2012), that nationally the number of adolescents who have premarital sexual relations has increased compared to the previous survey in 2007 in the Indonesian Youth Reproductive Health Survey (SKRRI) [1].

Based on Amoo's 2017 research that addresses the health problems of men and women with their implications for men in Nigeria. The findings show that $49.3 \%$ of respondents currently have more than one sex partner. The index of sexy partners for a lifetime of $70.2 \%$ of the men interviewed had sexy partners in their lives. It was revealed that men who resisted health challenges, such as sexually transmitted infections and genital ulcers, were $44 \%$ and $93 \%$ smaller, respectively, who were advised to enjoy good benefits. This also shows that men in urban areas are 7,256 times better off to enjoy good money conditions compared to men in the village [2]. The most important educational needs of adolescents include STD/HIV, reproductive anatomy and physiology, puberty and menstrual health common cancers among women and contraception. Comprehensive counseling includes family planning issues sexual and reproductive health services for adolescents, counseling about teen pregnancy, violent behavior, gender relations, sexual responsibility, sexually transmitted infection, and sexual assault prevention. Comprehensive counseling has the following characteristics: it reaches $100 \%$ of adolescents, involves all adolescents, parents, counselors, and community partners, developmental and sequential, unique and responsive services, focuses on needs and goals, and measures program effectiveness [3].

The princess program is one of the extracurricular programs in Muhammadiyah 4 Margahayu Middle School and isy Aisyiyah Rancaekek Middle School in Bandung Regency. Preliminary studies conducted by researchers, in this program there are adolescent reproductive health materials delivered for example about menstruation. This program is intended primarily for female students while waiting for male students to perform Friday prayers. Based on the background presentation, the researcher wants to know how the implementation of reproductive health learning policies or similar programs in this case is the princess program implemented in both junior high schools owned by the Muhammadiyah organization in the Bandung Regency.

\section{METHODS}

The research design is a qualitative research with a type of explorative descriptive research, to find a more in-depth and systematic picture of the implementation of adolescent reproductive health learning policies. As written by Sugiyono (2012) that this type of research is to describe phenomena systematically based on theoretical analysis and empirical data in accordance with the phenomena that occur [4]. 
Data collection techniques are done through in-depth interviews, observation and study of documentation. Techniques to guarantee the validity of the data in the research carried out triangulation, namely the techniques of checking the validity of the data that utilizes allies outside the data for the purposes of checking or comparison of existing data. Informant research subjects are recipients of reproductive health education, implementers and policy makers in the junior high school where the study was conducted. Informants are selected by means of purposive sampling, ie informants are chosen with consideration in accordance with the objectives of the study. Informants were selected based on inclusion criteria, where informants were recipients, implementers and policy makers who were in Muhammadiyah Sayati Middle School and Aisyiyah Rancaekek Middle School, willing to be participants and could provide information needed by researchers.

Data analysis technique is inductive data analysis, as according to the theory according to Croswell (2016) that inductive data analysis is to build patterns, categories and themes from the bottom up (inductive), by processing data into more information units abstract so that they can build a unified whole theme. Broadly speaking, the stages of data analysis are (1) transcription; (2) coding and data reduction; (3) description of the theme in the form of a qualitative report;

(4) interpretation and draw conclusions [4].

Ethical Clearance

Approval of research ethics was obtained from the Health Research Ethics Commission of the Ilmu Aisyiyah College of Health Bandung. Participation in research is only possible if approval has been obtained after an explanation from each participant that meets the criteria.

\section{RESULT AND DISCUSSION}

\section{A. Overview of Research Informants}

The research informants consisted of 8 students aged 13 and 14 years, the sex of all student informants were female and most were at grade 9 level. There were 5 teacher informants consisting of curriculum, student and class teachers, the rest were 2 informants headmaster

B. Implementation of Reproductive Health Education Policy Based on Communication Aspects

The results of the study showed that so far the policies especially on reproductive health education in schools were only delivered directly and verbally, there were no writings, either in the form of Decrees, or only announcements. This was stated by the Principal 1:

"Kalau jadwal paling-paling secara lisan saja bu, jadi tidak dilaporkan secara tertulis... saya tidak tahu kalau ada laporan tertulis ke kesiswaan atau ke kurikulum, kan yang menugaskan secara langsung mereka-mereka, yang bertanggungjawab tentang kegiatan itu" (KS1)

The results of the interview also stated that there was no clearly written technical flow of implementation, so far the implementation only followed the flow that was delivered directly by the manager who was also the educator in the program. This condition was also strengthened by the statements of students in 2 (two) schools with students who actively participated in the princess program, that so far there had been no announcement or schedule in writing and the results of interviews with students in both schools:

"Peraturannya disampaikan. Enak tertulis, mau banget ditulis, supaya kita bisa mengingat lagi gitu” (PS1-1)

So far, policy makers in schools have handed over responsibilities and entrusted programs related to reproductive health education to managers as well as educators in the program. There is no plot on how the regulations or techniques related to this activity should be implemented. The program has been able to be implemented, routinely every week but only known by managers, educators and students, so that there are aspects of communication that are not suitable for the implementation of reproductive health education policies in the 2 schools.

\section{Implementation of Reproductive Health Education Policy \\ Based on Resource Aspects \\ 1) Human Resources}

Based on the results of interviews conducted in 2 (two) schools, it shows that the human resource manager and educator of reproductive health education programs in schools is inadequate and not in accordance with qualifications in their fields. Both schools do not have health educators. In its implementation, the school entrusts mathematics, English and Biology teachers as managers as well as educators in the reproductive health program. The school principal at school 2 stated several reasons related to English teachers entrusted to become managers and educators in the reproductive health program:

“...kenapa Bu RN masuk di wilayah ini, ya tadi saya katakana ..ghirah organisasi, organisasi harus masuk..jadi karena sekolah Muhammadiyah, sekolah kader dan kami tadi ingin mewujudkan marwah pendidikan Muhammadiyah berdasarkan visi Muhammadiyah 2025, maka otomatis gagasan Muhammadiyah harus masuk, nah karena Bu RN sebagai aktifis NA, maka diapun otomatis harus bisa memberikan informasi tentang keputrian tapi tidak lepas dari cara-cara berorganisasi gaya ke-NA an..."

In addition, written evaluations relating to increased knowledge and program implementation have never been done, only limited to evaluation of attendance. This was stated by $\mathrm{HN}$ as manager and educator of the program:

“...kita melihat evaluasinya ya dari kehadiran guru, hadir tidak, kemudian kita juga kan ada insentifnya, jika program ini tidak dilaksanakan kan dilihat kan nanti ada kehadirannya dan insentif yang diberikan..."

\section{2) Facility Resources}

Based on the results of the interviews, the resource facilities in both schools showed the same conditions, namely having a room provided for the implementation of the program, namely prayer rooms, not rooms for learning of adolescent reproductive health. In accordance with the results of interviews with Principal 1, princess activities were carried out in large places such as prayer rooms. The same thing was also conveyed by the Principal 2 stating that the facilities and infrastructure used were not specifically intended for the sustainability of the program. 
“... untuk fasilitas memang belum begitu diistimewakan ya.. keputrian itu di mushola putri ya, mushola putri itu kan dibawah sini ya..ini no maden sih ya, masih pindahpindah, karena kita...sementara metodenya masih ceramah..kan gitu kan..jadi masiv lah, jadi belum spesifik..."

Other tools such as learning media, at both research sites, do not have media that is used specifically for learning, teachers only read from the internet and then delivered and discussed.

\section{3) Budget Resources}

Based on the results of the interviews, the budget resources provided have been integrated into the student budget as well as its management. As stated by EJ as Principal 2:

“Kalau anggaran kan begini....anggarannya kan ...di kesiswaan, itu dia melakukan apa namanya....mapping lah ya"

Regarding incentives, delivered by $\mathrm{HN}$, program managers and educators in schools 1 .

“...kita melihat evaluasinya ya dari kehadiran guru, hadir tidak, kemudian kita juga kan ada insentifnya, jika program ini tidak dilaksanakan kan dilihat kan nanti ada kehadirannya dan insentif yang diberikan"

\section{Implementation of Reproductive Health Education Policy Based on Disposition}

Based on the aspect of disposition, teachers as well as program managers in both schools feel this is their duty so that in its implementation, the program is carried out seriously even though the educational background is not in accordance with the program being run. Both schools have a goal so that students know the right thing to do in relation to reproductive health and adapted to Islamic jurisprudence, especially for women. This is also related to the vision of Muhammadiyah and Aisyiyah schools, which is to form superior, independent and Islamic individuals.

This was stated by RN from school 2:

"saya latar belakangnya kan selalu ikut organisasi di muhammadiyah jadi terus lihat kedekatan saya dengan anak-anak perempuan itu kan eee ke kelihatannya bagus gitu jadi ya sudah sama saya..."

This benefit was also felt immediately by a number of students who actively participated in the program.

"Kerasa, ya kan aku te pengen tau untuk menjadi perempuan yang baik sama solehah te gimana...” (PSDL)

\section{E. Bureaucratic Structure}

Bureaucratic structure in policy implementation consists of standard operational procedures (SOP) and fragmentation. The existence of SOPs allows everyone to work on the program as optimal as possible between other activities and equalize one's actions in a more complex and broad organization. The results showed there were no SOPs for learning adolescent reproductive health. This condition is supported by a statement from the principal informant who said: "teu aya (SOP) alur perencanaan program...monitoring selama ini Koordinasi sama guru yang sudah melaksanakan, yang tadi, misalnya bertanya tadi yang diberikan tentang masalah apa..oh tentang masalah anu...ke-Islaman ini..gitu aja bu, tinggal dtanya aja guru yang membimbing, sesuai dengan jadwalnya"

Problems that often arise in fragmentation problems are in accordance with the results of interviews that have been conducted, namely the difficulty in making coordination between units and the diffusion of accountability. Resources and authority are often controlled by someone or are personal to overcome a problem. This will also affect the implementation of optimal policy implementation.

\section{DISCUSSION}

\section{A. Communication}

Based on the results of the study, the implementation of the policy from the aspect of communication including the dimensions of transmission, clarity and consistency have not been implemented properly. The policy giver only instructs verbally, there is no writing as strong evidence of the policy to be carried out. According to Syarif, et al (2014), communication in policy implementation is useful to facilitate coordination, integration and synchronization of program implementation. Communication is only limited to verbal and this condition will weaken the sustainability of the program [5]. According to Lintjewas, Tulusan and Egetan in the research of Ramdhani et al (2017), the principal as a policymaker must be intensive in engaging two-way communication to analyze the consequences of a policy that is applied. Evaluation of policy implementation can be carried out at the planning stage, the implementation stage, and the post implementation stage [6].

The results of Ramadani's research (2019) reinforce that there needs to be unity between transmission, clarity and consistency. Channels or communication media used in research are learning preparation program meetings at the beginning of the year, and for program monitoring and evaluation conducted verbally along with program evaluations [8]. One way to clarify the matter is to distinguish among the concepts of information, behavior, and communication. Information can be conceived of as all stimuli in the environment that reduce uncertainty for the organism. That is, information is anything individuals use to gain predictability about the environment and to guide their behavior. The position of the sun in the sky is information about the time of day, but one would normally not call it a "message," because the sun did not establish its position for the purpose of signaling to observers what hour of the day it is on Earth. It is simply there as an environmental stimulus from which observers can draw inferences and adjust their own behavior Resources [7]. Resources have an important role in policy implementation. In a policy, if managers lack appropriate resources, implementation tends to be less effective. The resources referred to are in accordance with Edward III's theory in Subekti, Faozanudin and Rokhman (2017) are managers who have the capability in accordance with their fields to carry out their duties and responsibilities, 
facilities and infrastructure needed as well as the budget needed to run a policy [8].

The results showed aspects of resources that were already good in terms of facilities and budget, but in terms of human resources, learning of adolescent reproductive health was provided by educators who were not yet in accordance with their expertise, for example health executors or teachers who had been provided with health education information teenage reproduction. During this time, learning is provided by teachers with educational backgrounds in English, mathematics, biology and other fields. The side of the facilities where the activities are carried out is good, but there is no module or book guide. In addition to aspects of human resources, facilities and budgets, there is also the role of information and authority in the resource component to support the successful implementation of policies, as in Sjoraida's research in 2018 that the success of the implementation of public information disclosure policies in the Province of West Java was very dependent on how the implementation process was in achieving the mandated objectives of the policy. The implementation of decentralization patterns, though not wrong, is less effective in implementing public information services. In this pattern, standard public information services in each OPD are not the same, and difficulties in synergizing information services due to weak communication and coordination in the West Java Provincial Government (ie between OPD). Therefore, efforts to improve the centralization pattern are expected to improve service quality and public satisfaction [9].

\section{B. Disposition}

The results showed good results for the disposition side. All parties ranging from school principals, teachers and students have a strong desire to implement and participate in adolescent reproductive health learning. As policy implementers, each teacher in both research locations, has a commitment to carry out a reproductive health program or a princess program that is aligned with Islamic fiqh studies. In addition, the principal has an attitude of courage in directing the teacher, being disciplined and responsible, referring to the vision and mission of the school and working mindfully, but has not functioned clearly in teaching reproductive health learning. Edward III Theory as the main theory underlying research also writes that there are incentives in the disposition aspect. One technique for policy implementers to move well is the need for manipulation of incentives by policymakers by increasing profits or costs or salaries, so that it becomes a motivator or enthusiasm in carrying out orders properly [10]. The reality on the ground shows that there is already an incentive for implementers or teachers who provide materials when reproductive health learning activities are given, and is proven by the presence of teachers who are always present on a predetermined schedule.

\section{Bureaucratic Structure}

Bureaucratic structure according to Edward III Theory has two main characteristics, namely Standard Operating Procedure (SOP) and fragmentation. SOP is a clear path related to the certainty of time, resources and the need for uniformity in complex work organizations, while fragmentation is the spread of policy responsibilities into organizational units. The results of the study showed that they did not have a clear SOP regarding the flow of planning, implementation and evaluation in implementing programs as the implementation of policies. Fragmentation allows the distribution of responsibilities to several people or different units to manage a policy that requires coordination. The results showed that the fragmentation or distribution of reproductive health learning responsibilities were left to the students and teachers as implementers. According to the theory of Westra et al (1982) quoted from Faturrahman's research results that bureaucracy is a task marked by the implementation of organizational principles, rules that are actually obeyed, officials who work with all their attention and ability, officials are bound by discipline and officials appointed on the basis of technical requirements stated by examinations or diplomas and there is a strict separation between service and personal affairs. An effective bureaucratic structure is the entire apparatus or section that is truly aware of the importance of achieving the specified targets, both in terms of time and cost [11].

Based on observations and documentation, the structure of bureaucracy in learning reproductive health in the two research sites, no work description of program managers or related units was found, namely the student or curriculum section, there were no written documents regarding the implementation of program monitoring and evaluation. As the results of research Subekti et al (2017) that the division of labor, formalization, command lines and SOP can affect the effectiveness of BOS implementation in SDN in Tambak District [8].

\section{CONCLUSION}

The implementation of reproductive health education policy has not been appropriate in the aspects of communication, resources and bureaucratic structure, while in the disposition aspect there is already a good commitment from all parties to implement the policy and there are incentives as a motivator for the sustainability of the program to the end of the program.

\section{ACKNOWLEDGMENT}

The researcher would like to thank all those who have provided support during the course of the study from beginning to end. Thank you especially conveyed to the Ministry of Research, Technology and Higher Education as a buffer of research funds, the school as a place of research for the cooperation of time and energy provided and also to colleagues in the School of Health Sciences 'Aisyiyah Bandung. For this collaboration, may Allah SWT give a reward for the kindness given.

\section{REFERENCES}

V. Nuraldila and S. Yuhandini D, "Keterkaitan Pengetahuan Tentang Kesehatan Reproduksi Remaja Dengan Perilaku Seks Pra Nikah Pada Siswa-Siswi Kelas XI Di SMA PGRI 1 Kabupaten Majalengka Tahun 2017," J. Care, vol. 05, no. 3, pp. 431-442, 2017.

[2] E. O. Amoo, G. A. Oni, M. P. Ajayi, A. E. Idowu, T. O. Fadayomi, and A. K. Omideyi, "Are Men's Reproductive Health Problems and Sexual Behavior Predictors of Welfare?," Am. J. Mens. Health, vol. 11, no. 3, pp. 487-497, 2017 
[3] S. Panjalipour, Z. B. Khalesi, and S. N. Mirhaghjoo, "Iranian female adolescents' reproductive health needs: A systematic review," Int. J. Women's Heal. Reprod. Sci., vol. 6, no. 3, pp. 226232, 2018.

[4] J. W. Croswell, Research Design, 4th ed. Yogyakarta: Pustaka Pelajar, 2016.

[5] A. Syarif, A. A. Unde, and L. Asrul, "Pentingnya komunikasi dan informasi pada implementasi kebijakan penyelenggaraan penanggulangan bencana di Kota Makasar," J. Komun. KAREBA, vol. 3, no. 3 Juli-September, pp. 142-152, 2014.

[6] A. Ramdhani and M. A. Ramdhani, "Konsep Umum Pelaksanaan Kebijakan Publik," J. Publik, pp. 1-12, 2017.

[7] J. K. Burgoon, L. K. Guerrero, and K. Floyd, Nonverbal Communication, vol. 53, no. 9. New York: Routledge, 2019.

[8] A. R. Mening Subekti, Muslih Faozanudin, "Pengaruh
Komunikasi, Sumber Daya, Disposisi Dan Struktur Birokrasi Terhadap Efektifitas Implementasi Program Bantuan Operasional Sekolah Pada Satuan Pendidikan Sekolah Dasar Negeri Di Kecamatan Tambak," IJPA - Indones. J. Public Adm., vol. 3, no. 2, pp. 58-71, 2017.

[9] D. F. Sjoraida, A. Asmawi, and R. K. Anwar, "The spirit of democracy in the implementation of public information policy at the provincial government of West Java," IOP Conf. Ser. Earth Environ. Sci., vol. 126, no. 1, 2018.

[10] H. Hasibuan, Yusnadi, and P. Saut, "Implementasi Kebijakan STandar Kualifikasi Dan Kompetensi Kepala SMK Negeri Di Kabupaten Aceh Selatan," Pendidik. dan Kepengawasan, vol. 3, no. 2, pp. 33-49, 2016.

[11] M. Fahturrahman, "Faktor Birokrasi Dalam Keberhasilan Impelentasi Kebijakan Publik," vol. 2, no. 02, pp. 14-27, 2016. 